\title{
Carbon supported nano-sized Pt-Pd and Pt-Co electrocatalysts for proton exchange membrane fuel cells
}

\author{
F. Kadirgan ${ }^{a, *}$, A.M. Kannan ${ }^{b}$, T. Atilan ${ }^{a}$, S. Beyhan ${ }^{a}$, S.S. Ozenler ${ }^{a}$, S. Suzer ${ }^{c}$, A. Yörür $^{a}$ \\ ${ }^{a}$ Chemistry Department, Istanbul Technical University, Ayazaga Kampusu Maslak, Maslak-Istanbul 34410, Turkey \\ ${ }^{\mathrm{b}}$ Electronic Systems Department, Arizona State University, Mesa, AZ 85212, USA \\ ${ }^{\mathrm{c}}$ Chemistry Department, Bilkent University, 06800 Ankara, Turkey
}

\section{A R T I C L E I N F O}

Article history:

Received 6 April 2009

Received in revised form

11 September 2009

Accepted 11 September 2009

Available online 15 October 2009

Keywords:

CO tolerance

$\mathrm{Pt}-\mathrm{Pd} / \mathrm{C}$

$\mathrm{Pt}-\mathrm{Co} / \mathrm{C}$

Membrane-electrode assembly

PEM fuel cell

\begin{abstract}
A B S T R A C T
Nano-sized Pt-Pd/C and Pt-Co/C electrocatalysts have been synthesized and characterized by an alcohol-reduction process using ethylene glycol as the solvent and Vulcan XC$72 \mathrm{R}$ as the supporting material. While the $\mathrm{Pt}-\mathrm{Pd} / \mathrm{C}$ electrodes were compared with $\mathrm{Pt} / \mathrm{C}$ (20 wt.\% E-TEK) in terms of electrocatalytic activity towards oxidation of $\mathrm{H}_{2}$, $\mathrm{CO}$ and $\mathrm{H}_{2}-$ $\mathrm{CO}$ mixtures, the $\mathrm{Pt}-\mathrm{Co} / \mathrm{C}$ electrodes were evaluated towards oxygen reduction reaction (ORR) and compared with Pt/C (20 wt.\% E-TEK) and Pt-Co/C (20 wt.\% E-TEK) and Pt/C (46 wt.\% TKK) in a single cell. In addition, the $\mathrm{Pt}-\mathrm{Pd} / \mathrm{C}$ and $\mathrm{Pt}-\mathrm{Co} / \mathrm{C}$ electrocatalyst samples were characterized by XRD, XPS, TEM and electroanalytical methods. The TEM images of the carbon supported platinum alloy electrocatalysts show homogenous catalyst distribution with a particle size of about $3-4 \mathrm{~nm}$. It was found that while the $\mathrm{Pt}-\mathrm{Pd} / \mathrm{C}$ electrocatalyst has superior CO tolerance compared to commercial catalyst, $\mathrm{Pt}-\mathrm{Co} / \mathrm{C}$ synthesized by polyol method has shown better activity and stability up to $60^{\circ} \mathrm{C}$ compared to commercial catalysts. Single cell tests using the alloy catalysts coated on Nafion-212 membranes with $\mathrm{H}_{2}$ and $\mathrm{O}_{2}$ gases showed that the fuel cell performance in the activation and the ohmic regions are almost similar comparing conventional electrodes to Pt-Pd anode electrodes. However, conventional electrodes give a better performance in the ohmic region comparing to Pt-Co cathode. It is worth mentioning that these catalysts are less expensive compared to the commercial catalysts if only the platinum contents were considered.
\end{abstract}

๑ 2009 Professor T. Nejat Veziroglu. Published by Elsevier Ltd. All rights reserved.

\section{Introduction}

One of the challenges in proton exchange membrane fuel cells (PEMFC) is the requirement of very pure hydrogen (with much lower than $5 \mathrm{ppm} \mathrm{CO}$ ), which is typically produced via steam reforming or partial oxidation of natural gas, methanol, or other liquid fuels. The CO poisoning of the Pt catalysts leads to significantly decreased output power and energy efficiency [1-6]. Two possibilities of eliminating or decreasing the poisoning effect of $\mathrm{CO}$ are well known. The first is the increase of fuel cell working temperature [7-9]. It is shown that at about $200{ }^{\circ} \mathrm{C}$ the Pt catalysts can be tolerant up to a CO content of $20,000-30,000 \mathrm{ppm}$. The second way is based on development of new $\mathrm{CO}$ tolerant anodic catalysts. Bimetallic alloys are widely used as electrode materials in fuel cells, especially for the electro-oxidation of CO [10-13].

\footnotetext{
* Corresponding author. Tel.: +90 212285 3262; fax: +90 2122856386 .

E-mail address: kadirgan@itu.edu.tr (F. Kadirgan).

0360-3199/\$ - see front matter () 2009 Professor T. Nejat Veziroglu. Published by Elsevier Ltd. All rights reserved. doi:10.1016/j.ijhydene.2009.09.028
} 


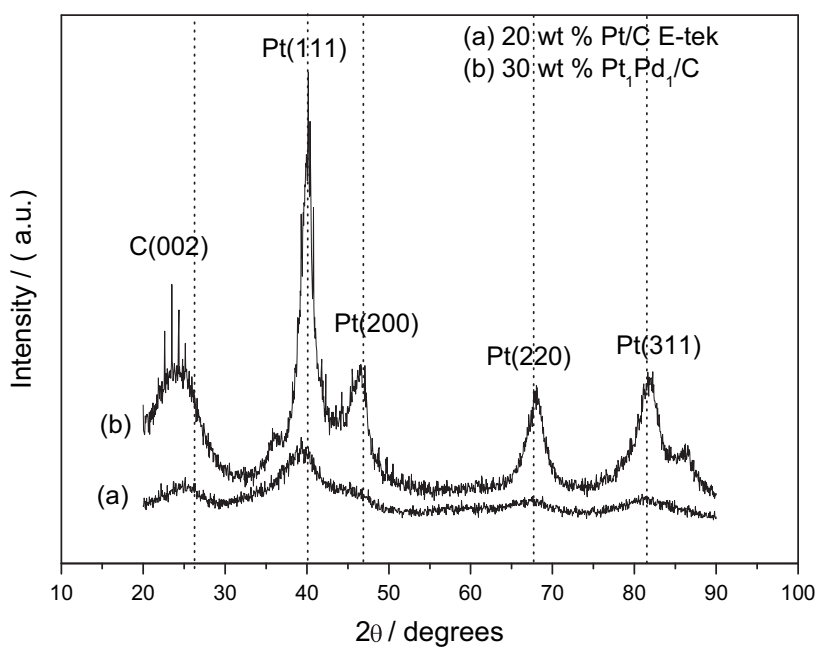

Fig. 1 - X-ray diffractograms of Pt/C, Pt-Pd/Vulcan XC-72R.

Two mechanisms are proposed for the improvement of $\mathrm{CO}$ tolerance by bimetallic alloys. One may be attributed to the facilitation of the $\mathrm{Pt}-\mathrm{CO}_{\mathrm{ads}}$ oxidation in the presence of a second metal by supplying oxygen atoms. The other is the ligand mechanism, wherein the electronic structure of $\mathrm{Pt}$ is modified by forming an alloy with the second metal. This results in weakening of the $\mathrm{CO}$ adsorption on platinum. Both of the two mechanisms imply that Pt and the promoting metals should be in intimate contact at the atomic scale or form alloy nano-clusters with compositional homogeneity [4]. Notable enhancement of the electrocatalytic activity of platinum has been observed by introducing a second metal: Pt-Ru [14,15], Pt-Sn [16,17], Pt-Pd [18-20], Pt-Rh [21], Pt-Mo [22]. Making alloys with a second or third metal is a convenient way to modify electrocatalytic properties of Pt in order to overcome the poisoning effects which results in lower surface coverage by the adsorbed CO.

Additionally, it is well known that most of the performance losses in PEMFCs stem from the poor kinetics of the

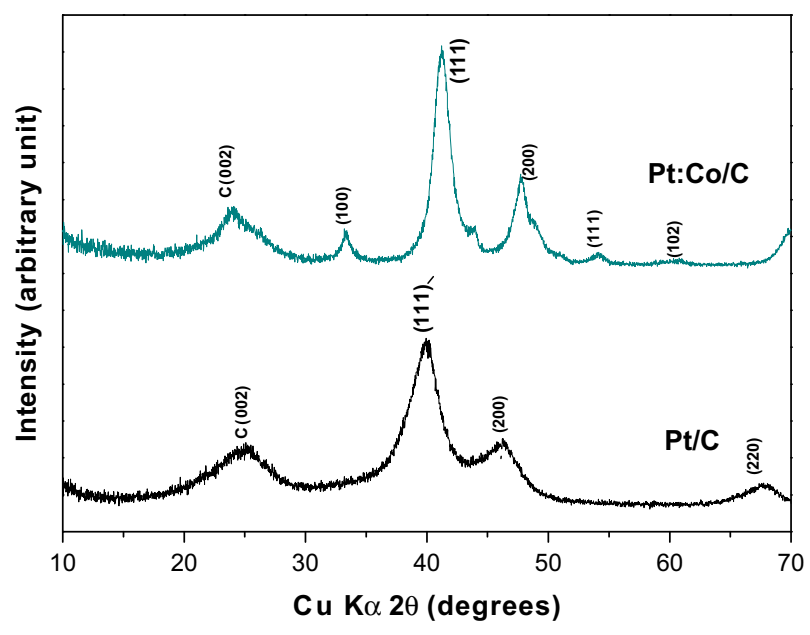

Fig. 2 - X-ray diffractograms of Pt/C and Pt-Co/Vulcan XC-72R.

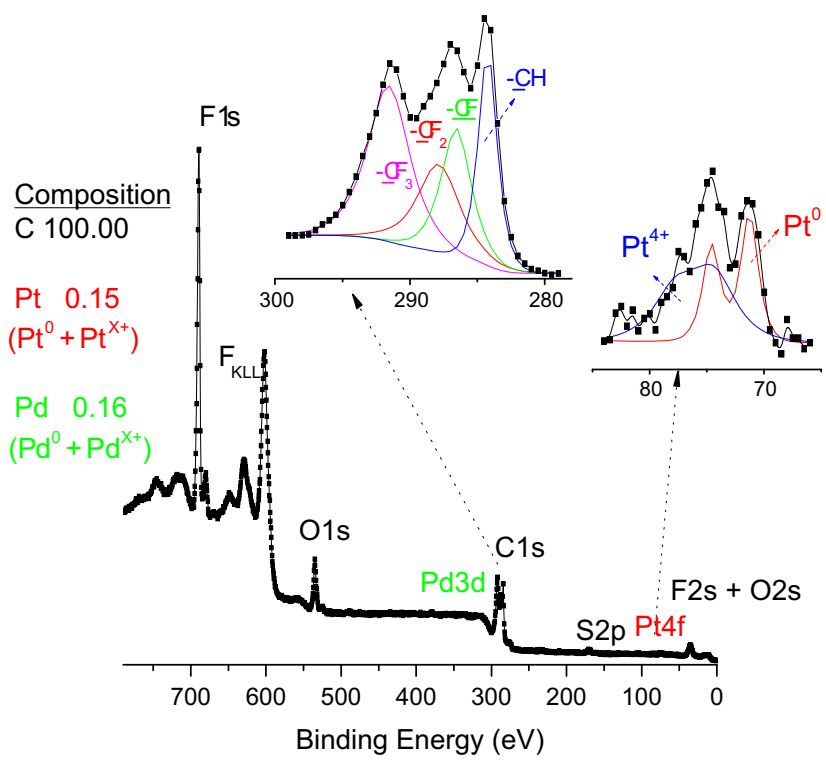

Fig. 3 - XPS spectra of Pt-Pd/Vulcan XC-72R.

oxygen reduction reaction (ORR). Many investigations have shown that Pt-based alloy electrocatalysts [22-28], such as $\mathrm{Pt}-\mathrm{M}$, (where $\mathrm{M}=\mathrm{Co}, \mathrm{Ni}, \mathrm{Fe}, \mathrm{V}, \mathrm{Mn}$ or $\mathrm{Cr}$ ) have significantly higher electrocatalytic activity towards ORR than platinum for PEMFCs. It has also been observed that the use of Pt-Co electrocatalysts for the ORR may improve the cell performance with respect to Pt alone in PEMFCs. On the basis of ORR activity versus $\mathrm{Pt}-\mathrm{Pt}$ bond distance on Co content in the alloy, the optimum Pt:Co atomic ratio was determined to be about 3:1 [23]. However, one of the authors' groups showed that the best performance with the maximum catalytic activity and minimum polarization using $\mathrm{Pt}: \mathrm{Co} / \mathrm{C}$ was obtained with an atomic ratio of around 1:7 prepared by a low temperature reduction procedure using sodium formate [28]. According to Arico et al. [29], the amount of platinum oxide in the alloy electrocatalysts decreases with increased Co content.

On the other hand, the high cost of the platinum is one of the reasons for its limited use. In fact, in order to improve the reaction kinetics and decrease the cost, it is necessary to develop new multi-functional catalysts. Thus, great efforts have been devoted to the development of fuel cell electrocatalysts with a focus in increasing their electrocatalytic activity and reducing the noble metal content [30-35]. Development of direct methanol fuel cell anode catalysts in recent years is reviewed focusing on exploration of a new development of catalysts with a low metal content and non-noble metal elements through combinatorial method, carbon supporting strategies and catalyst preparation methods [36]. Mainly Pt-Ru catalysts with respect to activity improvement and utilization optimization, preparation of novel carbon materials as catalyst supports to create a highly dispersed and stably supported catalyst have been the focus of various investigations. The role of nanostructured supports, such as ordered mesoporous carbon and electrocatalytic properties of various metals such as Pt-Ru, Pt-Sn, Pt-Mo, Pt-Ru-Mo-W, Pt-Ru-Os-IrO, Pt-Ir and 

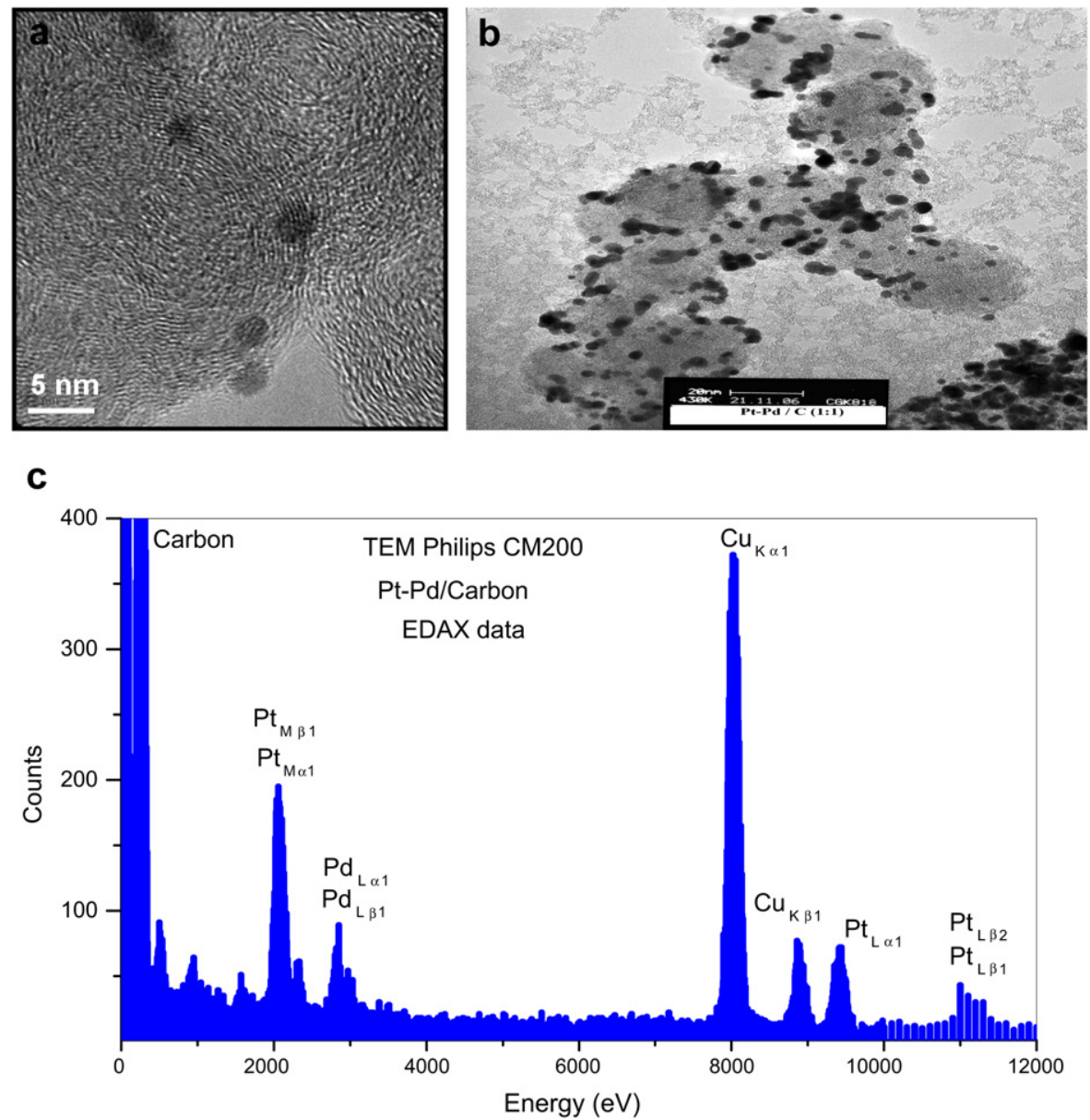

Fig. 4 - (a) High resolution TEM image of Pt-Pd/Vulcan XC-72R (scale bar $=5 \mathrm{~nm}$ ), (b) low magnification of TEM image of $\mathrm{Pt}-\mathrm{Pd} /$ Vulcan XC-72R (scale bar $=20 \mathrm{~nm}$ ) and (c) EDAX data of Pt-Pd/Vulcan XC-72R.

$\mathrm{Pt}-\mathrm{WO}_{3}$ are reviewed [37] specifically for applications in fuel cells. The performance that would be needed for a cost-free non-Pt catalyst is also defined to represent the most likely route for the automotive fuel cells in ref. [38] and references there in. CO tolerance of Pt rich platinum-palladium carbon electrocatalysts prepared by chemical reduction of their corresponding salts and formaldehyde as the reducing agent attained improved performance $[39,40]$, compared to both Pt and Pt-Ru for Pt:Pd (1:4), fraction at $80^{\circ} \mathrm{C}$. The electrocatalytic reactions through the study of model systems such as pure metal single crystals and well-characterized bulk alloys have been studied [41], as models for real electrocatalysts and some directions for developing more realistic systems have been proposed.

In the present study, carbon supported nano-sized Pt-Pd and Pt-Co electrocatalysts are prepared by the polyol process in the absence of surfactants. The electrocatalytic activity of $\mathrm{Pt}-\mathrm{Pd} / \mathrm{C}$ catalyst towards electro-oxidation of $\mathrm{H}_{2}, \mathrm{H}_{2}$ (2\%) $\mathrm{H}_{2}+2 \% \mathrm{CO} \mathrm{CO}$ and $\mathrm{CO}$ and electrocatalytic activity of $\mathrm{Pt}-\mathrm{Co} / \mathrm{C}$ for ORR are investigated and compared with a commercial $20 \mathrm{wt}$ \% Pt/C (E-TEK) and $46 \mathrm{wt} . \% \mathrm{Pt} / \mathrm{C}$ (TKK, Japan) electrocatalysts. The $\mathrm{Pt}-\mathrm{Pd} / \mathrm{C}$ and $\mathrm{Pt}-\mathrm{Co} / \mathrm{C}$ electrocatalyst samples are characterized by XRD, XPS and TEM. Nafion-212 electrolyte based membrane electrode assemblies are also prepared using $\mathrm{Pt}-\mathrm{Pd} / \mathrm{C}$ and $\mathrm{Pt}-\mathrm{Co} / \mathrm{C}$ electrocatalysts and single cell performances are evaluated with $\mathrm{H}_{2}$ and $\mathrm{O}_{2}$ at $70{ }^{\circ} \mathrm{C}, 100 \% \mathrm{RH}$.

\section{Experimental}

\subsection{Catalyst synthesis}

The amount of chemicals in metal bases are calculated from the stoichiometric ratio of metals in precursors. The Pt-Pd/C (with an atomic ratio of $1: 1)$ and $\mathrm{Pt-Co}(1: 1)$ catalysts were prepared using their salts such as $\mathrm{H}_{2} \mathrm{PtCl}_{6} \cdot 6 \mathrm{H}_{2} \mathrm{O}, \mathrm{PdCl}_{2}$ or $\mathrm{CoCl}_{2}$ on carbon black (Vulcan XC 72) supports. For the preparation of Pt-Co (1:1) catalysts; $11.67 \times 10^{-3} \mathrm{~g} \mathrm{CoCl}_{2}$ and $46.74 \times 10^{-3} \mathrm{~g}$ $\mathrm{H}_{2} \mathrm{PtCl}_{6} \cdot 6 \mathrm{H}_{2} \mathrm{O}$ is used. A total of $30 \%$ metal in weight of catalysts (Pt-Co) is prepared mixing $53.43 \times 10^{-3} \mathrm{~g} \mathrm{C}$ with $49.48 \times 10^{-3} \mathrm{~g}$ Pt-Co metal based salts. Vulcan XC-72R, $\mathrm{CoCl}_{2}$ and $\mathrm{H}_{2} \mathrm{PtCl}_{6}$ are dissolved in diethylene glycol, respectively. The solution is then heated to boiling temperature of the solvent $\left(\sim 245^{\circ} \mathrm{C}\right)$ under constant stirring and refluxed for $2 \mathrm{~h}$. After the suspension is allowed to cool to room temperature, the black precipitate is isolated by centrifugation and washed thoroughly with de-ionized water. As-synthesized samples 
a

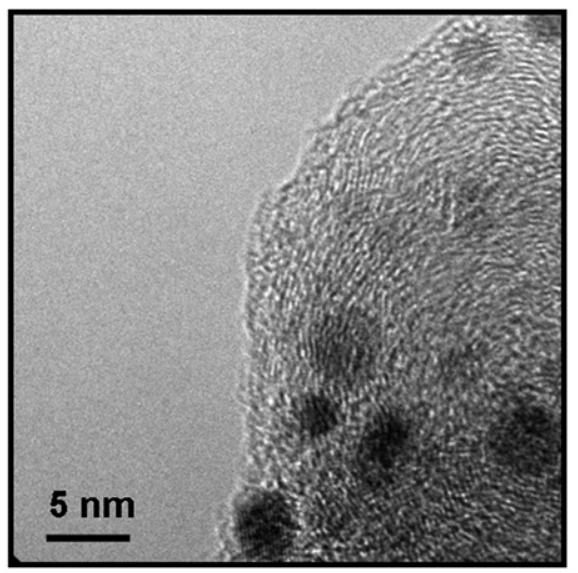

b

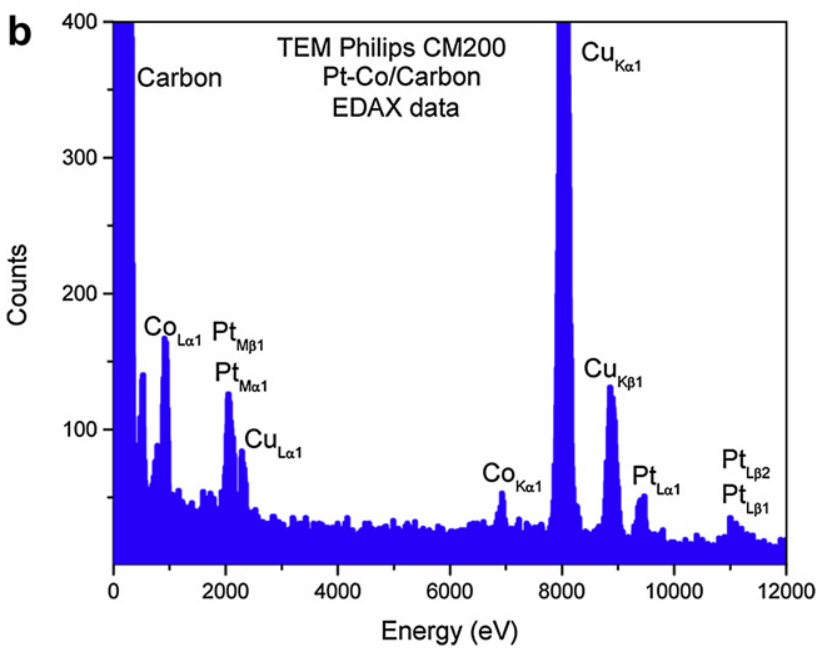

Fig. 5 - (a) TEM image of Pt-Co/Vulcan XC-72R (scale bar $=5 \mathrm{~nm}$ ) and (b) EDAX data of Pt-Co/Vulcan XC-72R.

are heat treated overnight at $90^{\circ} \mathrm{C}$ under vacuum. Catalyst containing ink solution was prepared by ultrasonic mixing of a solution containing $2 \mathrm{ml}$ water, $5.4 \mathrm{ml} \mathrm{Nafion} 5 \%$ and $900 \mathrm{mg}$ of catalysts. Then calculated quantity of ink (depending to the surface used) was applied on a glassy carbon electrode with an injection to obtain $10 \mu \mathrm{g} \mathrm{cm}^{-2}$ total metals loading for Pt/C, Pt$\mathrm{Pd} / \mathrm{C}$ and $\mathrm{Pt}-\mathrm{Co} / \mathrm{C}$.

The Pt-Pd (atomic ratio of 1:1) electrocatalyst (30 wt.\% on Vulcan XC-72R) is prepared by similar calculation way using $\mathrm{H}_{2} \mathrm{PtCl}_{6} \cdot 6 \mathrm{H}_{2} \mathrm{O}$ and $\mathrm{PdCl}_{2}$ precursors in ethylene glycol solvent. $\mathrm{PdCl}_{2}$ was first dissolved in ethylene glycol and stirred

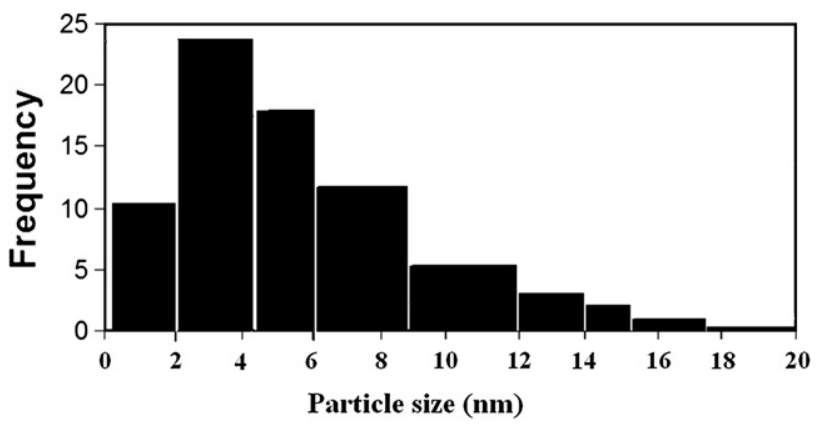

Fig. 6 - Particle size distribution of Pt-Co/Vulcan XC-72R.

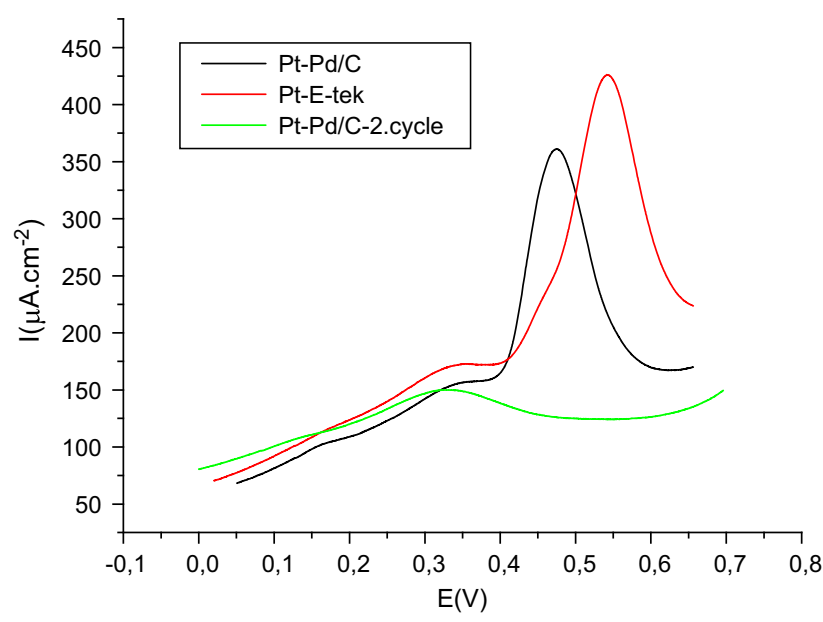

Fig. 7 - Comparison of the first and second cycle of CO stripping curves of $\mathrm{Pt} / \mathrm{C}$ (E-TEK) and Pt-Pd/C in $0.1 \mathrm{M} \mathrm{HClO}_{4}$ at $0.1 \mathrm{~V} / \mathrm{SCE}, 25^{\circ} \mathrm{C}, 20 \mathrm{mV} \mathrm{s}^{-1}$.

overnight at room temperature. Then, $\mathrm{H}_{2} \mathrm{PtCl}_{6} \cdot 6 \mathrm{H}_{2} \mathrm{O}$ is added to this solution. Finally, $\mathrm{NaOH}$ solution (in ethylene glycol) was added, and then heated in an oil bath to $160^{\circ} \mathrm{C}$ under flowing nitrogen gas for about $3 \mathrm{~h}$. After forming a dark brown colloidal solution, the Vulcan XC-72R is added. In order to deposit the unprotected catalyst metal nano-particles on the Vulcan $\mathrm{XC}-72 \mathrm{R}$, the $\mathrm{pH}$ is reduced to 1 . The resultant reaction product filtered and washed with de-ionized water and then dried at $110^{\circ} \mathrm{C}$ under vacuum overnight.

The catalysts synthesized are compared with Pt/C (E-TEK) 20 wt.\% and Pt-Co/C (E-TEK) 20 wt.\%.

\subsection{Gas diffusion layer}

Gas diffusion layers are fabricated with a teflonized non-woven carbon paper obtained from Hollingsworth \& Vose Company (West Groton, MA). Hydrophobic characteristic of the microporous layers is provided by TE5839 Teflon suspension (Dupont, Wilmington, DE). Vapour grown carbon fibre (VGCF-H) type carbon (Showa Denko America Inc., NY) is mixed with nanochain PUREBLACK ${ }^{\circledR}$ 205-110 Carbon (Superior Graphite Co., Chicago, IL) to provide improved mechanical strength and adhesion of the micro-porous layer with the macro-porous layer [36]. In order to fabricate the micro-porous layers, slurry of carbons (75 wt.\% pureback carbon and $25 \mathrm{wt} . \%$ nano-fibrous carbon (VGCF)) with PTFE dispersion (25 wt.\%) in isopropanol is prepared by ultrasonication followed by magnetic stirring, along with Novec 7200 dispersion agent (3M Electronics, MN). The slurry is coated on to the non-woven carbon paper using wire wound rods, obtained from RD Specialties, NY by a motorized set-up developed in-house. Subsequently, carbon paper with the micro-porous layer is dried at $150^{\circ} \mathrm{C}$ for $2 \mathrm{~h}$ and then sintered at $350^{\circ} \mathrm{C}$ in air for about an hour. The carbon loading for the microporous layer is between 2.5 and $3 \mathrm{mg} \mathrm{cm}^{2}$ with RDS50 wire rods.

\subsection{Catalyst coated membrane}

Catalyst coated membranes (CCM) with $5 \mathrm{~cm}^{2}$ active area are fabricated using Pt-Pd/Vulcan XC-72R, Pt-Co/Vulcan XC-72R 
Table 1 - Onset potential and maximum current values for $\mathrm{H}_{2}+2 \% \mathrm{CO}$ and CO stripping at $0.1 \mathrm{~V} / \mathrm{SCE}$ with a sweep rate of $20 \mathrm{mV} \mathrm{s}^{-1}$.

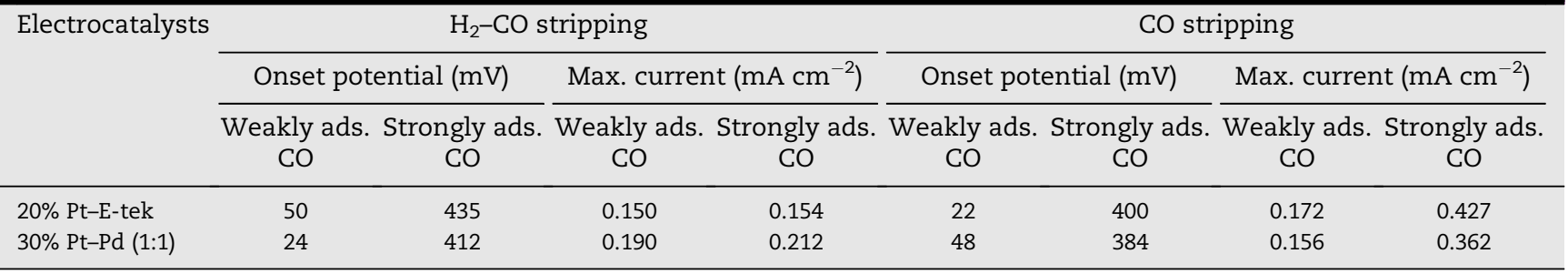

and commercial Pt/C catalyst (TKK, Japan) slurry in isopropanol (20 $\mathrm{ml}$ for $1 \mathrm{~g}$ of electrocatalyst) using the microspray method for anode and cathode sides on Nafion ${ }^{\circledR}$ membrane (NRE 212, Ion Power Inc., New Castle, DE). The isopropanol is added after purging the catalyst powder in flowing nitrogen gas for about $30 \mathrm{~min}$ to avoid any flame/ ignition. In order to extend the reaction zone of the catalyst layer, $5 \%$ Nafion ${ }^{\circledR}$ solution $(10 \mathrm{ml}$ Nafion solution for $1 \mathrm{~g}$ of electrocatalyst) is added to the catalyst slurry. The membrane is fixed in a home-made fixture to ensure anode and cathode catalyst layers are exactly on the same area of the membrane. The catalyst loadings on the anode and cathode sides are about 0.5 and $1 \mathrm{mg}$ catalyst $\mathrm{cm}^{2}$, respectively. The catalyst coated Nafion-212 membrane is vacuum dried at about $70{ }^{\circ} \mathrm{C}$ for an hour before assembling it in the fuel cell test cell.

\subsection{Membrane electrode assembly and fuel cell performance}

The GDLs and the CCM are assembled by just sandwiching inside the single cell test cell (Fuel Cell Technologies Inc, Albuquerque, NM). Gas sealing is carried out using silicone coated fabric materials (Product \#CF1007, Saint-Gobain Performance Plastics, USA) and with a uniform torque of $40 \mathrm{lb}$ in. The single cell fuel cell performance for various GDLs is evaluated at $70{ }^{\circ} \mathrm{C}$, and $100 \%$ RH using Greenlight Test Station (G50 Fuel cell system, Hydrogenics, Vancouver, Canada). The gas flow rates are fixed at 200 and 400 SCCM for hydrogen and $\mathrm{O}_{2}$, respectively. The steady state voltage values are collected

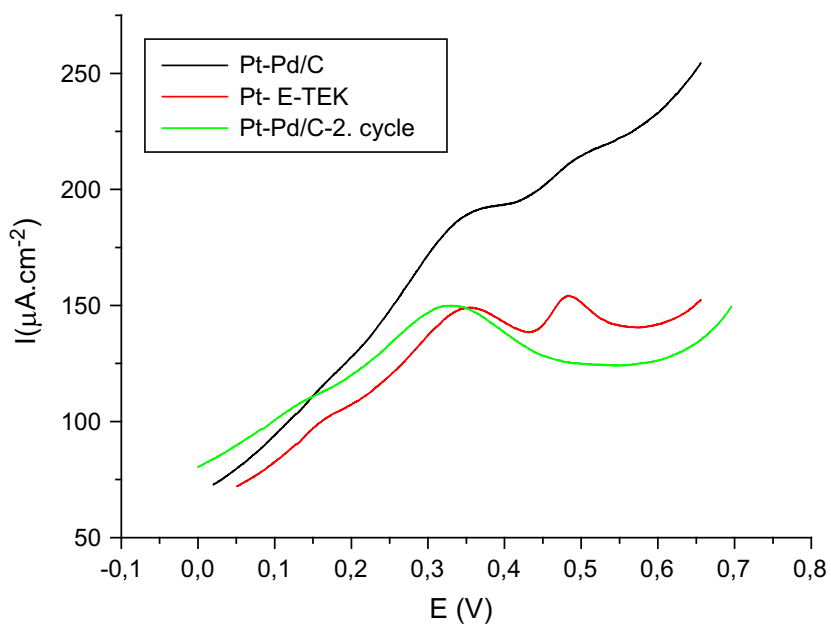

Fig. 8 - Comparison of the first and second cycle of $\mathrm{H}_{2}+(2 \%)$ CO stripping curve of Pt/C (E-TEK) and Pt-Pd/C in $0.1 \mathrm{M} \mathrm{HClO}_{4}$ at $0.1 \mathrm{~V} / \mathrm{SCE}, 25^{\circ} \mathrm{C}, 20 \mathrm{mV} \mathrm{s}^{-1}$. by holding the cell at each current density values for $60 \mathrm{~s}$. The performances of the single cells are measured by coupling the $\mathrm{Pt}-\mathrm{Pd} / \mathrm{C}$ as well as $\mathrm{Pt}-\mathrm{Co} / \mathrm{C}$ electrocatalysts with commercial Pt/C (TTK Catalyst, Japan) based electrodes [35].

\section{Characterization of catalysts}

\subsection{Spectroscopic methods}

The physical and chemical characteristics of catalyst are studied using the methods of X-ray photoelectron spectroscopy (XPS) and X-ray diffraction analysis (XRD). X-ray diffraction pattern of Pt/C (E-TEK) and the alloy catalysts are obtained using a diffractometer using $\mathrm{Cu} \mathrm{K} \alpha$ radiation at a scanning rate of $0.5^{\circ} \%$ min, and Kratos ES300 spectrometer is used for X-ray photoelectron spectroscopy (XPS) measurements using the K $\alpha$ lines of $\mathrm{Mg}(1253.6 \mathrm{eV})$ as the X-ray source. All lines were referenced to the $\mathrm{C} 1 \mathrm{~s}$ line at $285.0 \mathrm{eV}$. Peak fittings were done using the XPSPeak fit program.

\subsection{Microscopic methods}

Homogenously dispersed carbon supported Pt-Pd and the PtCo alloy catalyst samples in methanol are applied on a lacy carbon grid to examine the distribution and particle size of the Pt alloy particles by TEM using Philips CM200-FEG. In addition, the EDAX is also conducted for compositional analysis of the alloy catalyst samples.

\subsection{Electrochemical methods}

Electrochemical experiments are performed using a Voltalab PGZ-301 Electrochemical Impedance Spectrometer. The ink is applied with an injection on glassy carbon electrodes and allowed to dry in air at room temperature for $15 \mathrm{~min}$ to obtain $10 \mu \mathrm{g} \mathrm{cm}{ }^{2}$ of the electrocatalysts (metal content) loading. A classical three electrodes cell is used for the half cell measurements, using a saturated calomel electrode (SCE) and a Pt cage as the reference and counter electrodes, respectively. $0.1 \mathrm{M} \mathrm{HClO}_{4}$ (Merck, Suprapure) is used as supporting electrolyte.

\section{Results and discussion}

\subsection{Characterization of catalysts}

Fig. 1 shows the XRD patterns of $\mathrm{Pt} / \mathrm{C}, \mathrm{Pt}-\mathrm{Pd} / \mathrm{C}$, where the surface atomic ratio of $\mathrm{Pt}: \mathrm{Pd}$ is found to be $1: 1$ from XPS data. 

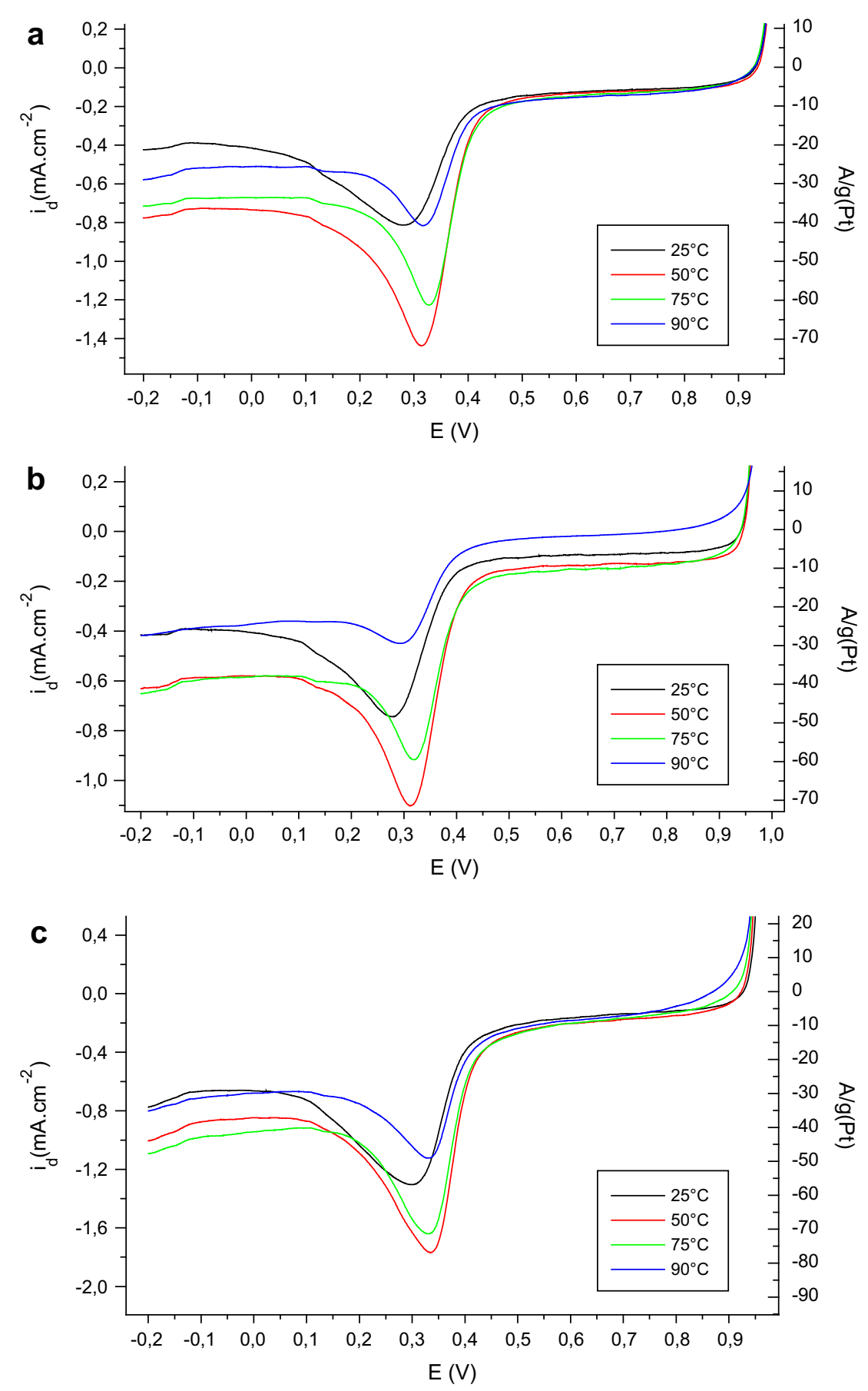

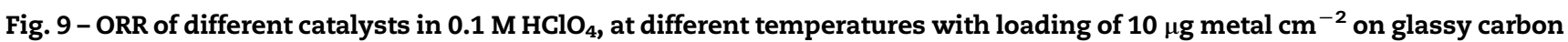
electrode and $20 \mathrm{mV} \mathrm{s}^{-1}$ sweep rate (a) on Pt/C E-TEK catalyst, (b) on Pt-Co/C E-TEK catalyst, and (c) on Pt-Co/C synthesized electrode by polyol methods.

From the shift of the XRD peaks it is possible to calculate the new cell parameter $\alpha_{\mathrm{Pt}-\mathrm{Pd}}$ using the following equation:

$\sin \theta=\left(\left(h^{2}+k^{2}+1^{2}\right)^{1 / 2}\right) / 2 \alpha($ a cubic structure $)$

The lattice parameters of Pt-Pd catalysts reflect the formation of an alloy calculated from Vegard's law for a pure Pt-Pd (58:42) alloy involving the incorporation of Pt and Pd atoms into the fcc structure. (Pt lattice parameter: $3.9161 \AA$; Pd lattice parameter: $3.8823 \AA$ and Pt-Pd lattice parameter: $3.896 \AA$ ). Fig. 2 gives the XRD patterns of $\mathrm{Pt} / \mathrm{C}$ and $\mathrm{Pt}-\mathrm{Co} / \mathrm{C}$. In all samples, apart from the first peak, related to carbon, only the reflexions corresponding to (111), (200) and (220), characteristic of the fcc structure of Pt were present. With the introduction of Co into the fcc structure of $\mathrm{Pt}$, the Pt reflections were shifted to higher values of $2 \theta$, which is indicative of a contraction of the lattice. No characteristic peaks of metallic Co or Co oxides were detected, but their presence cannot be 


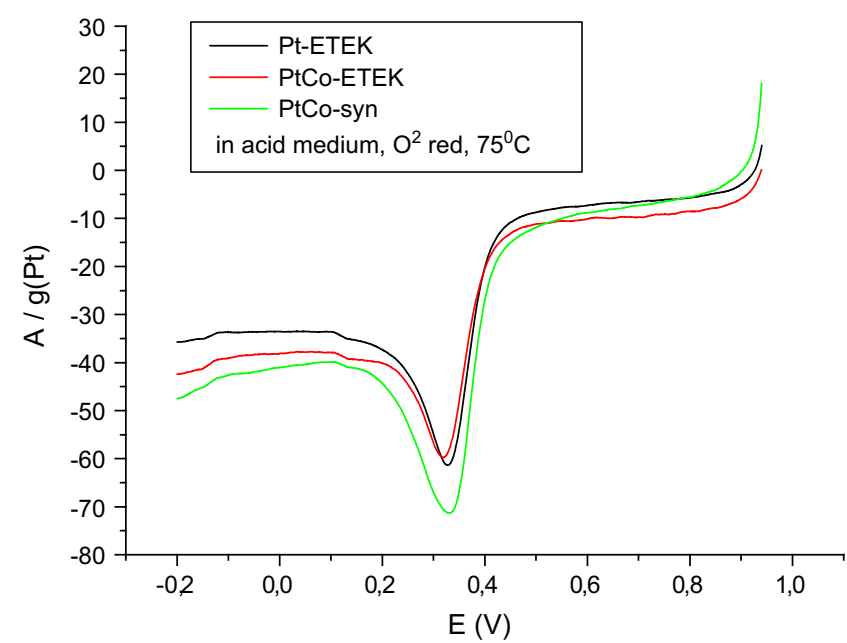

Fig. 10 - Comparison of ORR on Pt/C E-TEK, Pt-Co/C E-TEK and $\mathrm{Pt}-\mathrm{Co} / \mathrm{C}$ synthesized catalysts loaded glassy carbon electrodes at $75^{\circ} \mathrm{C}$ in $0.1 \mathrm{M} \mathrm{HClO}_{4}$, and $20 \mathrm{mV} \mathrm{s}^{-1}$.

discarded because they may be present in a very small amount or even in amorphous form.

Assuming that the dependence of the lattice parameter on Co content is the same for supported and unsupported Pt-Co alloys, the Co atomic fraction of carbon supported Pt-Co, can be obtained from Vegard's law. According to Vegard's law, assuming a linear dependence on Co atomic fraction, the lattice parameter of $\mathrm{Pt}_{3} \mathrm{Co}$ alloy obtained. (Pt lattice parameter: 3.92 ̊; Co lattice parameter: $3.54 \AA$ and Pt-Co lattice parameter: $3.85 \AA$ ).

The average crystallite platinum particle size of all the catalysts has been determined by both X-ray diffraction and transmission electron microscopy. The Scherrer formula $\left(L=k \lambda /\left(\beta_{1 / 2} \cos \theta\right)\right.$, where $L=$ effective crystalline diameter, $k=$ constant which was taken to be $0.9, \lambda=$ the wavelength of the incident X-rays, $\beta_{1 / 2}=$ the breadth of a diffraction peak at half height, and $\theta=$ the position of the peak maximum, has been used to estimate the size of the platinum particles from

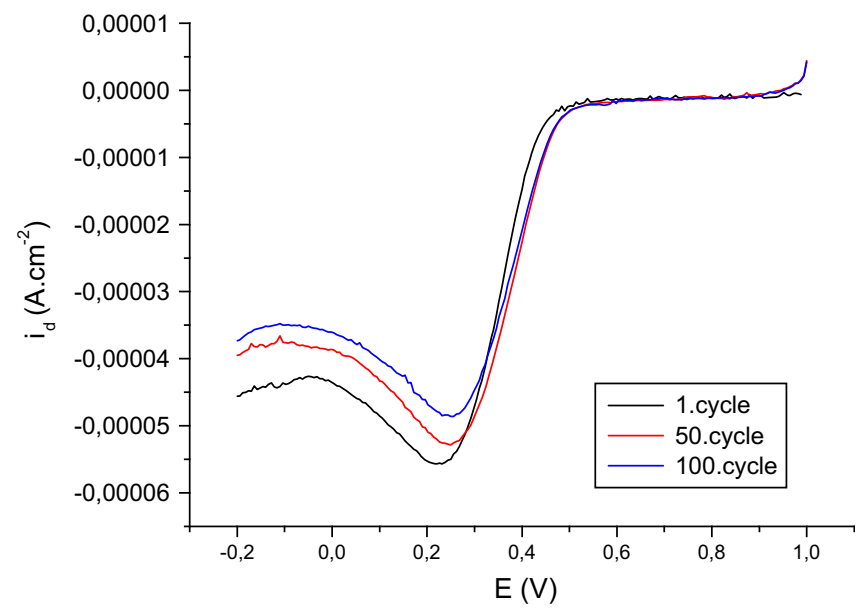

Fig. 11 - Accelerated corrosion test of Pt-Co/C synthesized catalysts loaded glassy carbon electrodes at $60^{\circ} \mathrm{C}$ in $0.1 \mathrm{M}$ $\mathrm{HClO}_{4}$, and $5 \mathrm{mV} \mathrm{s}^{-1}$ under ORR.

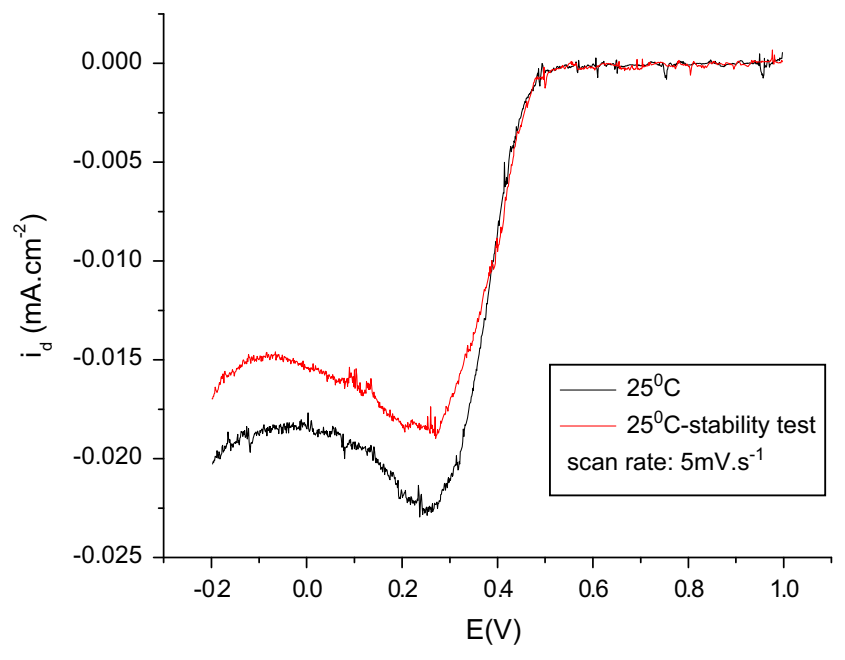

Fig. 12 - ORR on Pt-Co/C synthesized catalysts at $25^{\circ} \mathrm{C}$ before and after accelerated corrosion test.

the X-ray diffraction pattern. The average particle size of platinum-palladium and platinum-cobalt alloy catalysts is found to be about 3-4 $\mathrm{nm}$.

$\mathrm{X}$-ray photoelectron spectra of the catalysts indicate two different types of platinum as given in Fig. 3. As it is difficult to differentiate $\mathrm{Pt}^{2+}$ from $\mathrm{Pt}^{4+}$ over porous carbon support, these have been identified as $\mathrm{Pt}(0)$ and $\mathrm{Pt}^{\mathrm{x}+}$ (Pt (II) or Pt (IV)), which could be platinum oxide, hydroxide, or non-reduced Pt salt.

Figs. $4 a, b$ and $5 a$ show the high resolution and low magnification transmission electron microscope (TEM) images for the $\mathrm{Pt}-\mathrm{Pd} / \mathrm{C}$ and $\mathrm{Pt}-\mathrm{Co} / \mathrm{C}$ electrocatalysts, respectively. It is evident from these figures that the Pt alloy nanoparticles are uniformly distributed with average particle size ranging from 3 to $4 \mathrm{~nm}$ without any agglomeration, on the exterior of the carbon particles. Figs. $4 c$ and $5 b$ show the elemental analysis results by energy dispersive X-ray (EDAX) analysis and evidently there is no other impurity. The statistical analysis is carried out on the TEM images and the data is provided in Fig. 6 for Pt-Co/C. As seen from the figure, most of the particles are in the range of $3-4 \mathrm{~nm}$. The particle size distribution for $\mathrm{Pt}-\mathrm{Pd} / \mathrm{C}$ was identical to that of $\mathrm{Pt}-\mathrm{Co} / \mathrm{C}$ and hence not given here.

\subsection{Electrochemical measurements}

Electrochemically active surface area (ECA) of catalysts is measured from CO stripping curves and by cyclic voltammograms. For CO stripping voltammetry, the electrolyte $(0.1 \mathrm{M}$ $\mathrm{HClO}_{4}$ ) is saturated with $\mathrm{CO}$, and the electrode is immersed into the electrolyte under potential control and $\mathrm{CO}$ is adsorbed at $-0.1 \mathrm{~V}$ (SCE) for $3 \mathrm{~min}$ and then the CO is purged from the solution with pure $\mathrm{N}_{2}$. The first and second cycles are then recorded at $20 \mathrm{mV} \mathrm{s}^{-1}$ on the surface covered by the $\mathrm{CO}$ adlayer. Un-oxidized CO is not observed during the second cycle. The same experiments are realised also for $\mathrm{H}_{2} / 2 \% \mathrm{CO}$ mixture both on Pt/C E-Tek and Pt-Pd/C synthesized electrodes. CO stripping curves of Pt/C E-Tek (20 wt.\%) and Pt-Pd/C (1:1) (30 wt.\% metal 20 wt.\% Pt) catalysts are compared (keeping the 
Table 2 - Activation energy values of different electrodes at different potentials for ORR in $0.1 \mathrm{M} \mathrm{HClO}_{4}$.

\begin{tabular}{llcccrr}
$\mathrm{E}(\mathrm{V})$ & & 0.800 & 0.775 & 0.750 & 0.725 & 0.700 \\
\hline$\Delta \mathrm{H}^{*} /\left(\mathrm{kj} \mathrm{mol}^{-1}\right)$ & Pt/C E-TEK & 1.78413 & 1.88216 & 1.93137 & 2.30015 & 2.61129 \\
& PtCo/C E-TEK & 7.12867 & 7.50013 & 7.67609 & 7.71419 & 7.81222 \\
& PtCo/C synth & 1.56777 & 1.78681 & 2.75374 & 2.81444 & 3.28986 \\
\hline
\end{tabular}

total metal loading at $10 \mu \mathrm{g} \mathrm{cm}^{-2}$ ) in Fig. 7. The specific surface areas of electrodes are calculated from CO stripping curves and cyclic voltammograms. The values calculated are following:

Pt/C (TTK Catalyst, Japan): $44 \mathrm{~m}^{-2} \mathrm{~g}$;

Pt/C E-Tek: $128 \mathrm{~m}^{-2} \mathrm{~g}$;

$\mathrm{Pt}-\mathrm{Pd} / \mathrm{C}: 41 \mathrm{~m}^{-2} \mathrm{~g}$; and

Pt-Co/C: $40 \mathrm{~m}^{-2} \mathrm{~g}$.

According to Fig. 7, two potential regions can be distinguished both on Pt/C E-Tek and Pt-Pd/C synthesized catalysts, during oxidation of $\mathrm{CO}$ adsorbed. The first potential region (between 0.1 and $0.4 \mathrm{~V} / \mathrm{SCE}$ ) corresponds to the electro-oxidation of the weakly adsorbed state of $\mathrm{CO}$ and the second one (beginning from $0.4 \mathrm{~V} / \mathrm{SCE}$ ) corresponds to the electro-oxidation of the strongly adsorbed CO (Table 1). It is important to note that a reduction in the charge, corresponding to $\mathrm{CO}$ adsorption, is observed for both potential ranges on bimetallic catalysts. While only a decrease of charge is obtained for weakly adsorbed CO on Pt-Pd/C synthesized relatively to Pt/C E-Tek catalyst, a negative shift of oxidation peak potential $(\sim 0.08 \mathrm{~V})$ was assisted to the decrease of charge for CO strongly adsorbed on $\mathrm{Pt}-\mathrm{Pd} / \mathrm{C}$ electrodes. Upon sweeping the potential positively from $-0.1 \mathrm{~V}$, the onset of the strongly adsorbed $\mathrm{CO}$ oxidation is shifted approximately by $0.03 \mathrm{~V} . \mathrm{H}_{2} / 2 \% \mathrm{CO}$ mixture stripping curves of Pt/C E-TEK (20 wt.\%) and Pt-Pd/C (1:1) (30 wt.\% metal $20 \mathrm{wt} . \% \mathrm{Pt}$ ) catalysts are compared in Fig. 8. The pre-oxidation region is also observed in the polarization curve for the $\mathrm{H}_{2} / 2 \% \mathrm{CO}$ mixture. It is clearly evident that the transition from the poisoned surface to the unpoisoned surface is related to the stripping of the strongly adsorbed $\mathrm{CO}$ at $0.4 \mathrm{~V}$. Hydrogen

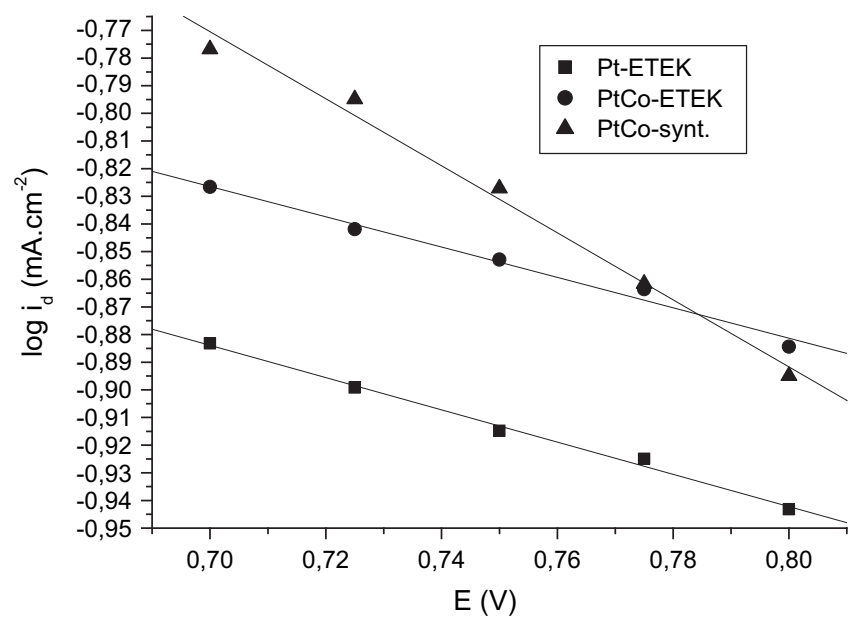

Fig. 13 - Tafel plots for ORR on Pt/C E-TEK, Pt-Co/C E-TEK and $\mathrm{Pt}-\mathrm{Co} / \mathrm{C}$ synthesized catalysts loaded glassy carbon electrodes at $75^{\circ} \mathrm{C}$ in $0.1 \mathrm{M} \mathrm{HClO}_{4}$, and $20 \mathrm{mV} \mathrm{s}^{-1}$. oxidation activity is $\sim 1.4$ times more at $0.4 \mathrm{~V}$ for synthesized $\mathrm{Pt}-\mathrm{Pd} / \mathrm{C}$ electrodes relatively to Pt/C E-Tek electrode.

It is observed that charge corresponded to the weakly and strongly adsorbed $\mathrm{CO}$ is decreased both in the case of $\mathrm{CO}$ and $\mathrm{H}_{2} / 2 \% \mathrm{CO}$ on Pt-Pd/C synthesized relatively to Pt-E-Tek (Table 1). Furthermore, the onset potential corresponding to the oxidation of $\mathrm{CO}$ is observed at more negative potentials than Pt (about $25 \mathrm{mV}$ for $\mathrm{H}_{2} / 2 \% \mathrm{CO}$ admixture). The negative shifts on $\mathrm{Pt}-\mathrm{Pd} / \mathrm{C}$ electrodes both for oxidation potential of $\mathrm{CO}$ and on set potentials can be due to the promoting effect of palladium toward CO oxidation. When palladium alloys with platinum the oxidation kinetics of $\mathrm{CO}$ is improved. The enhanced activity may be attributed to electronic effect.

It is well known that most of the performance losses in PEM fuel cells come from the cathodic reactions. Oxygen can be electrochemically reduced either directly to water without intermediate formation of $\mathrm{H}_{2} \mathrm{O}_{2}$,ad (direct $4 \mathrm{e}^{-}$reduction) or to $\mathrm{H}_{2} \mathrm{O}_{2}$,ad ( $2 \mathrm{e}^{-}$reduction) and the adsorbed peroxide can be electrochemically reduced to water ( $4 \mathrm{e}^{-}$pathway). Then, it can be catalytically or chemically decomposed on the electrode surface or desorbed into the bulk of the solution ([41] and references there in). It is also observed for Pt and Pt bimetallic catalysts that there is no splitting of the $\mathrm{O}-\mathrm{O}$ bond before a peroxide species is formed. Peroxide, on the other hand may or may not be further reduced to water. In either case, the rate determining step, appears to be the addition of the first elec-

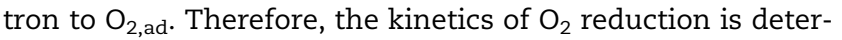
mined either by the free platinum sites available for the adsorption of $\mathrm{O}_{2}$ and/or by the change of Gibbs energy of adsorption of reaction intermediates with $\mathrm{OH}_{\mathrm{ad}}$. It is also found that the activity of all three low-index platinum planes is significantly higher in $\mathrm{HClO}_{4}$ than $\mathrm{H}_{2} \mathrm{SO}_{4}$, probably because of bisulphate adsorption onto the surface blocking the initial adsorption of $\mathrm{O}_{2}$.

Several investigations have been carried out to determine the role of alloying in the electrocatalytic activity of Pt for the oxygen ORR. In this work, carbon supported nano-sized Pt-Co (1:1) electrocatalysts prepared by polyol method are tested for ORR in half cells. The effect of temperature on the ORR and stability of the catalysts (Pt/C E-TEK, Pt-Co/C E-TEK and Pt-Co/C synthesized) with increasing temperature is investigated keeping the total metal loading $10 \mu \mathrm{g} \mathrm{cm}^{-2}$ on a glassy $\mathrm{C}$

Table 3 - Tafel slopes and number of electrons exchanged for ORR at $75^{\circ} \mathrm{C}$ in $0.1 \mathrm{M} \mathrm{HClO}_{4}$ with a sweep rate of $20 \mathrm{mV} \mathrm{s}^{-1}$.

\begin{tabular}{lcc} 
Electrocatalysts & $(\delta \log i / \delta$ E $)$ & $n$ \\
\hline Pt/C E-TEK & 0.602 & 0.086 \\
PtCo/C E-TEK & 0.373 & 0.052 \\
PtCo/C synth & 1.076 & 0.149 \\
\hline
\end{tabular}




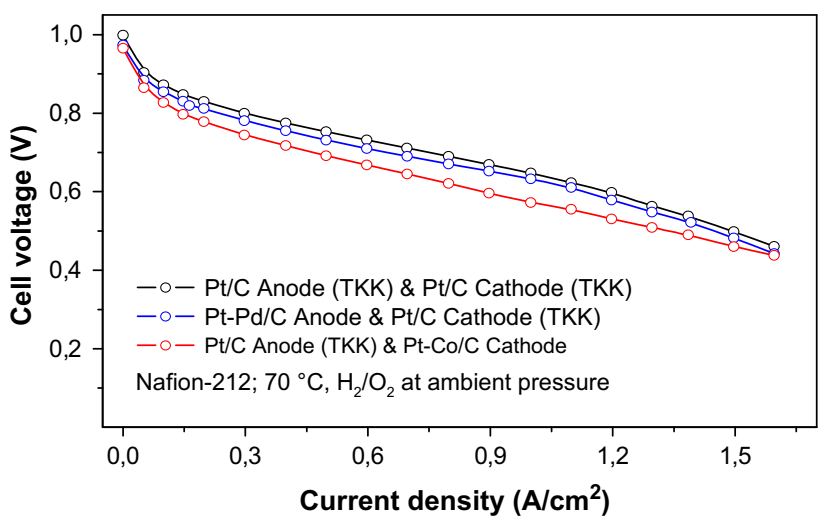

Fig. 14 - Fuel cell performance curves for (a) Pt/C (TKK) anode \& Pt/C (TKK) cathode, (b) Pt-Pd/C anode \& Pt/C cathode, and (c) Pt/C anode \& Pt-Co/C cathode based MEAs with Nafion-212 electrolyte at $70{ }^{\circ} \mathrm{C}, 100 \% \mathrm{RH}$ using $\mathrm{H}_{2} / \mathrm{O}_{2}$ at ambient pressure.

electrode under the same experimental conditions (Figs. 9a-c). To compare the results, current scale is also given as $\mathrm{A} / \mathrm{g}(\mathrm{Pt})$ at $(\mathrm{z})$ axis because $\mathrm{Pt} / \mathrm{C}$ E-TEK, Pt-Co/C E-TEK and Pt-Co/C synthesized contains $20 \%, 15,35 \%$ and $23 \%$ platinum, respectively. $\mathrm{O}_{2}$ reduction activity decreases at $90^{\circ} \mathrm{C}$, for all of the three electrodes. These three catalysts are then compared for their ORR activity at 75 \&deg;C (Fig. 10). Comparing the result of Pt-Co/C ETEK and Pt/C E-TEK at $75^{\circ} \mathrm{C}$, we have observed an increase of current at positive and negative potentials relatively to maximum reduction potentials for Pt-Co/C E-TEK electrode. However oxygen reduction current was about $12 \mathrm{~A} / \mathrm{g}(\mathrm{Pt})$ more for synthesized $\mathrm{Pt}-\mathrm{Co} / \mathrm{C}$ at maximum reduction potential relatively to Pt/C E-TEK, Pt-Co/C E-TEK. We have checked the I-V curves of catalysts under $\mathrm{N}_{2}$ purged supporting solution. Any decrease of activity is definitely not in the survey scans up to $90^{\circ} \mathrm{C}$ for all three catalysts. However, accelerated corrosion tests in half cells are realized at different temperatures. In this test, the entire active surface of the catalyst is exposed to the $0.1 \mathrm{M}$ $\mathrm{HClO}_{4}$ by cycling continuously under ORR conditions (about 100 cycle) with a scan rate of $5 \mathrm{mV} \mathrm{s}^{-1}$. High proton mobility in the liquid results in more severe catalyst corrosion than that observed in the MEA. Under these conditions, the deterioration of the catalysts is accelerated from $60^{\circ} \mathrm{C}$. Fig. 11 shows the current decay under ORR conditions between first, 50th and 100 th cycles at $60^{\circ} \mathrm{C}$. After 100 cycles at $60^{\circ} \mathrm{C}$, the catalytic activity of Pt-Co alloy is checked again at $25^{\circ} \mathrm{C}$ for ORR and compared to that of the first cycle obtained at $25^{\circ} \mathrm{C}$ before cycling at $60^{\circ} \mathrm{C}$. Difference of the current density observed both at $60^{\circ} \mathrm{C}$ after first and 100 th cycles and at $25^{\circ} \mathrm{C}$ before and after 100thcycles at $60^{\circ} \mathrm{C}$ (Fig. 12) may be attributed to the surface corrosion of the electrode at high temperatures. Similar results are observed in the literature and current decay is attributed to metal dissolution [42].

Activation energies calculated at different potentials for three electrodes are given in Table 2. It is observed that activation energies (ca. $1.6 \mathrm{~kJ} \mathrm{~mol}$ at $0.8 \mathrm{~V}$ ) for $\mathrm{Pt}-\mathrm{Co} / \mathrm{C}$ is similar to those obtained with $\mathrm{Pt} / \mathrm{C}$ (E-Tek). This implies that the reaction mechanism on Pt-Co/C alloy surfaces is the same as the one proposed for Pt/C (E-Tek). Tafel slopes and the number of electrons exchanged are observed from Fig. 13 for three electrodes and are given in Table 3, which led us to suggest the existence of the adsorption step on the reaction kinetic. A significant improvement of the ORR on $\mathrm{Pt}-\mathrm{Co} / \mathrm{C}$ alloy surfaces may imply an inhibition of $\mathrm{OH}_{\mathrm{ad}}$ formation above $0.8 \mathrm{~V}$. It was difficult to observe the true effect of Co sites on the adsorption properties of Pt atoms. However, we could suggest that Co may change the distribution of platinum or the local bonding geometry (the structure effect). It could also directly modify the reactivity of the platinum atoms (the electronic effect).

Fig. 14 compares synthesized catalysts with conventional electrodes in single cell. The polarization performance of single cell PEM fuel cells for MEAs fabricated with Pt/C anode (TKK) \& Pt/C cathode (TKK), Pt-Pd/C anode \& Pt/C cathode (TKK) and Pt/C anode (TKK) \& Pt-Co/C cathode based catalysts and with Nafion-212 electrolyte are compared at $70^{\circ} \mathrm{C}$, and $100 \% \mathrm{RH}$ using $\mathrm{H}_{2} / \mathrm{O}_{2}$ at ambient pressure. As seen from the Fig. 14, although the fuel cell performance in the activation and the ohmic regions are too similar compared to conventional electrodes using Pt-Pd anode electrodes, conventional electrodes give a slightly better performance in the ohmic region comparing to $\mathrm{Pt}-\mathrm{Co}$ cathode. Since the resistivity is the sum of ohmic resistance due to membrane, electrodes, contact resistance, etc., and all the samples are prepared using the same membrane, contact resistance, ink preparation method, etc., ohmic drop can be attributed to the nonnoble Co presence and corrosion of Co in the catalyst layer prepared by the polyol method.

However, the mass activity $(\mathrm{mA} / \mathrm{mg}$ of $\mathrm{Pt})$ is insignificant for Pt-Pd/C and Pt-Co/C based MEAs compared to Pt/C (TKK) anode and cathode based MEA, if only the Pt metal content is considered. It is worth mentioning that these catalysts are less expensive compared to the commercial catalysts. However, the long term performance stability of the $\mathrm{Pt}-\mathrm{Pd} / \mathrm{C}$ as well as $\mathrm{Pt}-\mathrm{Co} / \mathrm{C}$ catalysts needs to be performed before they are considered for any commercial viability.

\section{Conclusions}

The present study clearly demonstrates the potential of Ptbased binary alloys for use in the PEM fuel cells. In this work, polyol methods are used for the synthesis of Pt-based binary alloys to obtain particle size in the range of $3-4 \mathrm{~nm}$. An improvement of CO tolerance for the Pt-Pd/C electrocatalysts is definitely observed compared to that of Pt/C. Based on the results obtained, the inhibition of the poisoning effects could be attributed to the inability of carbon monoxide to fully occupy the vacant sites for hydrogen adsorption and eventual oxidation on the bimetallic catalyst. Our results show that for $\mathrm{Pt}-\mathrm{Pd} / \mathrm{C}$, both $\mathrm{Pt}$ and $\mathrm{Pd}$ atoms contribute to the activity. Hydrogen oxidation should more effectively proceed on Pt, so in principle it is the accessibility of free Pt sites that is more important. This seems to be guaranteed by an overall decrease of $\mathrm{CO}$ coverage on the catalyst particles which is induced by the synergistic effect Pd on Pt with increasing number of defects on the Pt nano-particles and enhancement of the overall reaction by decreasing the electrode poisoning. Moreover, Pd can also act as a supplier of hydrogen atoms, by 
providing vacant adjacent sites for hydrogen molecules to dissociate.

$\mathrm{Pt}-\mathrm{Co} / \mathrm{C}$ catalysts prepared by reduction with diethylene glycol can be considered a promising material for PEM fuel cells. Although it is very difficult to separate the structure, electronic and distribution effects of Co on Pt-Co alloys, it is reasonable to propose that the electronic effects may play the major role in the $\mathrm{Pt}-\mathrm{OH}_{\mathrm{ad}}$ energetic, thus in the reactivity of platinum surface atoms. It is well known that the size, shape and distribution of the atoms on the alloy depend on the preparation conditions and the method for the Pt-Co alloy. So their preparations and investigations as presented in this work by reduction with diethylene glycol help to identify important aspects of the polyol reduction methods to prepare supported catalysts and to understand the properties of the resulting materials.

Comparing the polarization curves in single cell with conventional electrodes, the nano-structured thin catalyst layers showed a slightly higher ohmic resistance. However these catalysts are less expensive than commercial catalysts. The stability of Pt-Co/C electrodes is still limited yet, particularly at temperatures above $60^{\circ} \mathrm{C}$, and hence the application is limited to low temperature fuel cells. Further research is in progress for improving the stability of $\mathrm{Pt}-\mathrm{Co} / \mathrm{C}$ electrocatalysts.

\section{Acknowledgments}

The authors thank The Scientific and Technical Research Council of Turkey (Project No: TBAG 104T358) and The Scientific Research Fund of Istanbul Technical University for financial assistance.

\section{Appendix A \\ Supplementary material}

Supplementary information for this manuscript can be downloaded at doi:10.1016/j.ijhydene.2009.09.028.

\section{R E F E R E N C E S}

[1] Jow J-J, Yang S-W, Chen H-R, Wu M-S, Ling T-R, Wei T-Y. Co-electrodeposition of Pt-Ru electrocatalysts in electrolytes with varying compositions by a double-potential pulse method for the oxidation of $\mathrm{MeOH}$ and $\mathrm{CO}$. International Journal of Hydrogen Energy 2009;34(2):665-71.

[2] Ambrosio EP, Francia C, Manzoli M, Penazzi N, Spinelli P. Platinum catalyst supported on mesoporous carbon for PEMFC. International Journal of Hydrogen Energy 2008;33(12):3142-5.

[3] Hsieh C-T, Lin J-Y, Wei J- L. Deposition and electrochemical activity of Pt-based bimetallic nanocatalysts on carbon nanotube electrodes. International Journal of Hydrogen Energy 2009;34(2):685-93.

[4] Batista EA, Malpass GRP, Motheo AJ, Iwasita T. New mechanistic aspects of methanol oxidation. Journal of Electroanalytical Chemistry 2004;571(2):273-82.

[5] Han DM, Guo ZP, Zeng R, Kim CJ, Meng YZ, Liu HK. Multiwalled carbon nanotube-supported $\mathrm{Pt} / \mathrm{Sn}$ and $\mathrm{Pt} / \mathrm{Sn} /$
$\mathrm{PMo}_{12}$ electrocatalysts for methanol electro-oxidation. International Journal of Hydrogen Energy 2009;34(5):2426-34.

[6] Manasilp A, Gulari E. Selective CO oxidation over Pt/alumina catalysts for fuel cell applications. Applied Catalysis B-Environmental 2002;37(1):17-25.

[7] Zhang JL, Xie Z, Zhang JJ, Tang Y, Song C, Navessin T, et al. High temperature PEM fuel cells. Journal of Power Sources 2006;160(2):872-91.

[8] Tang YH, Zhang JJ, Song CJ, Liu H, Zhang J, Wang H, et al. Temperature dependent performance and in situ AC impedance of high-temperature PEM fuel cells using the Nafion-112 membrane. Journal of the Electrochemical Society 2006;153(11):A2036-43.

[9] Xu H, Song Y, Kunz HR, Fenton JM. Operation of PEM fuel cells at $120-150^{\circ} \mathrm{C}$ to improve CO tolerance. Journal of Power Sources 2006;159(2):979-86.

[10] Lamy C, Lima A, LeRhun V, Delime F, Coutanceau C, Leger J-M. Recent advances in the development of direct alcohol fuel cells (DAFC). Journal of Power Sources 2002; 105(2):283-96.

[11] Beden B, Kadirgan F, Lamy C, Leger JM. Electrocatalytic oxidation of methanol on platinum-based binary electrodes. Journal of Electroanalytical Chemistry 1981;127(1-3):75-85.

[12] Beden B, Kadırgan F, Lamy C, Leger JM. , Oxidation of methanol on a platinum electrode in alkaline medium: effect of metal ad-atoms on the electrocatalytic activity. Journal of Electroanalytical Chemistry 1982;142(1-2):171-90.

[13] Lamy C, Rousseau S, Belgsir EM, Coutanceau C, Leger J-M. Recent progress in the direct ethanol fuel cell: development of new platinum-tin electrocatalysts. Electrochimica Acta 2004;49(22-23):3901-8.

[14] Gasteiger HA, Markovic NM, Ross Jr PN. Methanol electrooxidation on well-characterized platinum-ruthenium bulk alloys. Journal of Physics and Chemistry 1993;97(46): 12020-9.

[15] Hoster H, Iwasita T, Baumgastuer H, Vielstich W. Pt-Ru model catalysts for anodic methanol oxidation: influence of structure and composition on the reactivity. Physical Chemistry Chemical Physics 2001;3(3):337-46.

[16] Jansenn MMP, Moolhuysen J. Platinum-tin catalysts for methanol fuel cells prepared by a novel immersion technique, by electrocodeposition and by alloying. Electrochimica Acta 1976;21(11):861-8.

[17] Frelink T, Visscher W, Cox AP, JAR van Veen. Ellipsometry and dems study of the electrooxidation of methanol at Pt and Ru- and Sn-promoted Pt. Electrochimica Acta 1995;40(10): 1537-43.

[18] Kadırgan F, Beden B, Leger JM, Lamy C. Synergistic effect in the electrocatalytic oxidation of methanol on platinum + palladium alloy electrodes. Journal of Electroanalytical Chemistry 1981;125(1):89-103.

[19] Dalbay N, Kadirgan F. Electrolytically co-deposited platinum-palladium electrodes and their electrocatalytic activity for ethylene glycol oxidation: a synergistic effect. Electrochimica Acta 1991;31(2):353-6.

[20] Lopes T, Antolini E, Gonzalez ER. Carbon supported Pt-Pd alloy as an ethanol tolerant oxygen reduction electrocatalyst for direct ethanol fuel cells. International Journal of Hydrogen Energy 2008;33(20):5563-70.

[21] Koch DFA, Rand DAG, Woods R. Binary electrocatalysts for organic oxidations. Journal of Electroanalytical Chemistry 1976;70(1):73-86.

[22] Neto AO, Perez J, Napporn WT, Ticlanelli EA, Gonzalez ER. Electrocatalytic oxidation of methanol: study with Pt:Mo dispersed catalysts. Journal of Brazilian Chemical Society 2000;11(1):39-43.

[23] Salgado JRC, Antolini E, Gonzales ER. Structure and activity of carbon-supported Pt-Co electrocatalysts for oxygen 
reduction. Journal of Physical Chemistry B 2004;108(46): 17767-74.

[24] Ye S, Vijh AK. Cobalt-carbonized aerogel nanocomposites electrocatalysts for the oxygen reduction reaction. International Journal of Hydrogen Energy 2005;30(9): 1011-5.

[25] García-Contreras MA, Fernández-Valverde SM, VargasGarcía JR, Cortés-Jácome MA, Toledo-Antonio JA, ÁngelesChavez C. Pt, PtCo and PtNi electrocatalysts prepared by mechanical alloying for the oxygen reduction reaction in $0.5 \mathrm{M} \mathrm{H}_{2} \mathrm{SO}_{4}$. International Journal of Hydrogen Energy 2008;33(22):6672-80.

[26] Toda $\mathrm{T}$, Igarashi $\mathrm{H}$, Watanabe $\mathrm{M}$. Enhancement of the electrocatalytic $\mathrm{O}_{2}$ reduction on Pt-Fe alloys. Journal of Electroanalytial Chemistry 1999;460(1-2):258-62.

[27] Paffett MT, Berry GJ, Gottesfeld S. Oxygen reduction at $\mathrm{Pt}_{0.65} \mathrm{Cr}_{0.35}, \mathrm{Pt}_{0.2} \mathrm{Cr}_{0.8}$ and roughened platinum. Journal of the Electrochemical Society 1988;135(6):1431-6.

[28] Xiong L, Kannan AM, Manthiram A. Pt-M ( $\mathrm{M}=\mathrm{Fe}, \mathrm{Co}$, Ni and $\mathrm{Cu}$ ) electrocatalysts synthesized by an aqueous route for proton exchange membrane fuel cells. Electrochemistry Communications 2002;4(11):898-903.

[29] Arico AS, Shukla AK, Kim H, Park S, Min M, Antonucci V, et al. An XPS study on oxidation states of Pt and its alloys with $\mathrm{Co}$ and $\mathrm{Cr}$ and its relevance to electroreduction of oxygen. Applied Surface Science 2001;172(1-2):33-40.

[30] Arenz M, Stamenkovic V, Blizanac BB, Mayrhofer KJ, Markovic NM, Ross PN, et al. Carbon-supported Pt-Sn electrocatalysts for the anodic oxidation of $\mathrm{H}_{2}, \mathrm{CO}$, and $\mathrm{H}_{2} /$ $\mathrm{CO}$ mixtures. Part II: the structure-activity relationship. Journal of Catalysis 2005;232(2):402-10.

[31] Stamenkovic V, Arenz M, Blizanac BB, Ross PN, Markovic NM. Oxidation of $\mathrm{CO}$ and surface properties of well characterized $\mathrm{Pt}_{3} \mathrm{Sn}$ bimetallic alloy surfaces. Journal of New Materials for Electrochemical Systems 2004;7(2):125-32.

[32] Koper MTM. Electrocatalysis on bimetallic and alloy surfaces. Surface Science 2004;548(1-3):1-3.
[33] Grgur BN, Markovic NM, Ross PN. The electro-oxidation of $\mathrm{H}_{2}$ and $\mathrm{H}_{2} / \mathrm{CO}$ mixtures on carbon-supported $\mathrm{Pt}_{\mathrm{x}} \mathrm{Mo}_{\mathrm{y}}$ alloy catalysts. Journal of the Electrochemical Society 1999;146(5): 1613-9.

[34] Schmidt TJ, Noeske M, Gasteiger HA, Behm RJ. Electrocatalytic activity of PtRu alloy colloids for $\mathrm{CO}$ and $\mathrm{CO} /$ $\mathrm{H}_{2}$ electrooxidation: stripping voltammetry and rotating disk measurements. Langmuir 1997;13(10):2591-5.

[35] Kannan AM, Munukutla L. Carbon nano-chain and carbon nanofibers based gas diffusion layers for proton exchange membrane fuel cells. Journal of Power Sources 2007;167(2):330-5.

[36] Liu H, Song C, Zhang L, Zhang J, Wang H, Wilkinson DP. A review of anode catalysis in the direct methanol fuel cell. Journal of Power Sources 2006;155(2):95-110.

[37] Chan KY, Ding J, Ren J, Cheng S, Tsang YK. Supported mixed metal nanoparticles as electrocatalysts in low temperature fuel cells. Journal of Materials Chemistry 2004;14(4):505-16.

[38] Gasteiger HA, Kosha SS, Sompalli B, Wagner TF. Activity benchmarks and requirements for Pt, Pt-alloy, and non-Pt oxygen reduction catalysts for PEMFCs. Applied Catalysis B, Environmental 2005;56(1-2):9-35.

[39] Papageorgopoulos DC, Keijzer M, Veldhuis JBJ, De Bruijn FA. $\mathrm{CO}$ tolerance of Pd-rich platinum palladium carbonsupported electrocatalysts - proton exchange membrane fuel cell applications. Journal of the Electrochemical Society 2002;149(11):A1400-4.

[40] Rybalka KV, Tarasevich MR, Grafov BM, Bagdanovskaya VA, Beeketaeva LA, Loubnin EN, et al. Binary Pt- and Pd-based electrocatalysts for oxidation of hydrogen with $\mathrm{CO}$ admixtures. Journal of New Materials for Electrochemical Systems 2007;10(2):81-9.

[41] Markovic NM, Ross Jr PN. Surface science studies of model fuel cell electrocatalysts. Surface Science Reports 2002; 45(4-6):117-229.

[42] Coĺn-Mercado HR, Popov BN. Stability of platinum based alloy cathode catalysts in PEM fuel cells. Journal of Power Sources 2006;155:253-63. 